\title{
Haematological and serum biochemical values in Norwegian sled dogs before and after competing in a $600 \mathrm{~km}$ race
}

\author{
Tuva Holt Jahr ${ }^{1 *}$, Marte Ekeland Fergestad ${ }^{2}$, Ola Brynildsrud ${ }^{3}$, Hege Brun-Hansen $^{1}$ and Ellen Skancke ${ }^{1}$
}

\begin{abstract}
Background: Long-distance racing is known to cause alterations in haematological and serum biochemical parameters in sled dogs. Given that finishing status reflects the physical condition in dogs completing a race, such variations will mainly be the result of physiological adaption achieved during endurance exercise. However, changes observed in withdrawn dogs may indicate pathological conditions. The aim of this study was to reveal changes in haematological and serum biochemical values in sled dogs participating in a long-distance race, with emphasis on the withdrawn dogs. Sixty-five sled dogs participated in a clinical prospective cohort study: 46 dogs competed in the $600 \mathrm{~km}$ race (25 finishing and 21 withdrawn dogs), and 19 dogs served as controls. Blood sampling was performed early in the training season and after the race.

Results: When compared to control dogs, both withdrawn and finishing dogs showed significant increases in neutrophil count, C-reactive protein, blood urea nitrogen and sodium/potassium ratio. Significant decreases were found in erythrocytes and eosinophil cell count, and in haematocrit, haemoglobin, total protein, albumin, globulin, creatinine, potassium and calcium levels. Finishing dogs presented significant increases in white blood cells, large unstained cells, monocyte count and cortisol level compared to control dogs. In contrast, withdrawn dogs had significant elevations in alanine aminotransferase and alkaline phosphatase activity, as well as parameters associated with muscle metabolism, such as aspartate aminotransferase, creatine kinase and phosphorus concentration.

Conclusions: Competing sled dogs experienced minor changes in blood parameters in general, mainly revealing the same pattern among withdrawals and finishers. This might indicate that numerous changes simply reflect physiological adaption due to endurance exercise. However, the serum concentration of muscle enzymes was significantly increased only in the withdrawals, and were well above reference ranges. This reflects muscle degradation, which could be the main cause of performance failure in some of the withdrawals.
\end{abstract}

Keywords: Biochemistry, Haematology, Long distance race, Muscle enzymes, Sled dog

\section{Background}

Endurance exercise in sled dogs is associated with haematological and serum biochemical changes [1-4], although the underlying causes are not completely known. Most changes are considered to reflect normal physiological alterations due to heavy exercise, extreme

\footnotetext{
${ }^{*}$ Correspondence: tuva.holt.jahr@nmbu.no

${ }^{1}$ Department of Companion Animal Clinical Sciences, Faculty of Veterinary Medicine, Norwegian University of Life Sciences, PO Box 8146 Dep, 0033 Oslo, Norway

Full list of author information is available at the end of the article
}

energy demands and environmental challenges during racing. However, many dogs are withdrawn due to physical exhaustion, lameness or medical reasons, including pneumonia, blood loss secondary to gastric ulceration, enteritis and rhabdomyolysis [5, 6]. Hence, some of the observed changes during racing may have pathophysiological origin. In addition, factors such as breed, sex and age, as well as different handling and feeding strategies prior to and during racing, may have an influence.

The aim of this study was to identify and evaluate serum biochemical and haematological alterations in 
dogs participating in a genuine endurance race, focusing on the withdrawn sled dogs. The results from blood samples retrieved early in the training season were compared with samples taken immediately after race participation. Dogs training for the race, but not competing, served as the control group. The results from withdrawn and finishing dogs were compared to the controls.

\section{Methods}

\section{Study design and population}

\section{Clinical prospective cohort study}

Sled dogs $(n=65)$ from four different mushers were included. They were all possible candidates for participation in "Femundløpet", a Norwegian long-distance race of $600 \mathrm{~km}$, in February 2013. All dogs participated in training during the fall and winter 2012-2013. The dogs were classified by age (years), sex (female/male) and ownership (owner 1-4). Information regarding health, training and feeding routines during the training season was collected from the mushers via questionnaires.

The dogs were divided into three cohorts based on participation and outcome of the race: finishing dogs (cohort 1) $(\mathrm{n}=25)$, withdrawn dogs (cohort 2$)(\mathrm{n}=21)$ and nonparticipation/control dogs (cohort 3) $(\mathrm{n}=19)$ (Table 1). Cohort 2 was defined as dogs that discontinued the race. The reasons for withdrawal were not specified. The study group has been featured in a previous report [7].

\section{Blood sample collection}

Two blood samples from each dog were taken during training season in October 2012 (A samples) and after the race in February 2013 from finishers, withdrawals and controls (B samples). Samples from the three cohorts were further subdivided into A1 and B1 (finishers), A2 and B2 (withdrawals) and A3 and B3 (non-participants/ controls) (Table 1).

During the training season, the dogs had rested and fasted for a minimum of $12 \mathrm{~h}$ prior to blood sampling. Blood sampling was performed at the mushers' homes.
Blood samples from the finishers were collected as soon as possible and within $1.5 \mathrm{~h}$ after the dogs crossed the finish line. The dogs were not fed prior to blood sampling. Blood samples from the withdrawals were collected at the checkpoints as soon as possible and within $8 \mathrm{~h}$ after the dogs were dismissed from the race. Any feeding prior to sampling in these dogs was recorded. Feeding along the trail between the checkpoints was not recorded.

Post-race samples from the controls were collected at the mushers' homes 2 weeks after the race. The dogs had participated in normal training during the time of the race and the following weeks. They had rested and not been fed for a minimum of $12 \mathrm{~h}$ prior to sampling.

\section{Blood sampling and storage}

Blood was retrieved from the cephalic vein; $6 \mathrm{~mL}$ in tubes without anticoagulant and $3 \mathrm{~mL}$ in EDTA tubes were collected. Tubes without anticoagulant were centrifuged for $10 \mathrm{~min}$ after coagulation had occurred and within $1 \mathrm{~h}$ after blood collection, and the serum was immediately transferred to empty plastic tubes.

Pre-race samples from all dogs and post-race serum samples from the controls were kept in a cooler. All serum samples were transferred to a freezer $\left(-70{ }^{\circ} \mathrm{C}\right)$ in approximately 3-4 h, while the EDTA tubes were kept cooled overnight and analysed the next day.

Post-race serum samples from finishers were kept in a cooler and relocated to $-20^{\circ} \mathrm{C}$ within $1 \mathrm{~h}$ of sampling. The samples from the withdrawals were collected at different checkpoints and kept in a cooler outdoors at approximately $-5{ }^{\circ} \mathrm{C}$ after centrifuging. The serum samples from these dogs were transferred to $-20{ }^{\circ} \mathrm{C}$ within 2 days after collection. All post-race serum samples were kept frozen during transport and then transferred to $-70{ }^{\circ} \mathrm{C}$ for storage at the Norwegian University of Life Sciences. All post-race EDTA tubes were kept cool during the race and analysed the day after the end of the race.

The serum samples were analysed during March 2013.

Table 1 Cohorts and sampling groups. Blood samples from each dog were retrieved prior to the training season (A sample), and after the race (B sample). The dogs were divided in three groups; finishers, withdrawals and nonparticipants/controls

\begin{tabular}{|c|c|c|}
\hline \multicolumn{3}{|c|}{ Blood sampling during training season, fall 2012 (A samples) } \\
\hline Cohort 1 (A1 samples) & Cohort 2 (A2 samples) & Cohort 3 (A3 samples) \\
\hline In training & In training & In training \\
\hline$n=25$ & $n=21$ & $n=19$ \\
\hline \multicolumn{3}{|c|}{ Blood sampling after the race, 2013 (B samples) } \\
\hline Cohort 1 (B1 samples) & Cohort 2 (B2 samples) & Cohort 3 (B3 samples) \\
\hline Finishing dogs & Withdrawn dogs & Non-participating/control dogs \\
\hline
\end{tabular}




\section{Analysis}

Analysis of haematological and serum biochemical parameters was performed at The Central Laboratory, Norwegian University of Life Sciences. Serum biochemical parameters, except cortisol, were analysed by ADVIA 1800 (Siemens), and haematological parameters were analysed by ADVIA 2120 (Siemens). Serum cortisol was analysed using IMMULITE 2000 (Siemens). The laboratory's own reference ranges were employed (Tables 2 and 3).

\section{Statistical analysis}

All statistical analyses were performed in R 3.3.1 [8]. Variable correlation was explored using correlation plots from the psych package [9]. The variable breed was excluded from further analysis due to high collinearity to owner. Feeding regimen was left out due to a lack of variation. In the following, biochemistry and haematological variables were converted to represent the (absolute) change in the variable between post-race (B samples) and pre-race (A samples). Our statistical model thus focused on (average) changes within a single dog. First, all A-samples were compared by ANOVA (or, in the case of severely non-normally distributed parameters such as creatine kinase, Kruskal-Wallis tests) to evaluate homogeneity between the cohorts prior to racing. Cohorts were found to be comparable for all parameters (data not shown). Associations with demographic variables were carried out using 1000 bootstrap replicates of a linear regression model with the following variables used as predictors: Cohort (with control dogs as the reference group), owner, sex (reference: female) and age (< or $\geq 5$ years). For each bootstrap replicate, the covariate coefficients were kept. The median coefficient was then extracted from the list of 1000 bootstrap replicates. The P-value was calculated as followed; First, approximate normality of the bootstrapped coefficient list was asserted through normality plots (not shown). Then, a Student's t-value was calculated by dividing the mean of the coefficient list by the standard deviation of the list. We then used the distribution function for Student's $t$ (with the degrees of freedom left in the model) to get the P-value for this result. (Null hypothesis: that this list of 1000 coefficient covariates could have been sampled if the true coefficient value was 0 , i.e., that the coefficient is significantly different from 0 ). The parameter creatine kinase (CK) deviated significantly from normality but conformed well to a normal distribution after taking the logarithm. The parameters lipase and total bilirubin could not be transformed to normality and were later excluded from analysis. For these parameters, we evaluated difference in cohorts with the Kruskal-Wallis test instead. In the boxplots of Fig. 1 we first used ANOVA (on the logarithmic transformations) to investigate any cohort differences, then $\mathrm{t}$-tests to check for any between-group

Table 2 Median values and ranges for haematological values in all dogs in training, withdrawals, finishers and controls, along with reference range

\begin{tabular}{|c|c|c|c|c|c|c|c|c|c|}
\hline $\begin{array}{l}\text { Haematology } \\
\text { parameters }\end{array}$ & $\begin{array}{l}\text { Reference } \\
\text { range }\end{array}$ & $\begin{array}{l}\text { Median } \\
\text { pre-race } \\
\text { all dogs } \\
(n=46)\end{array}$ & $\begin{array}{l}\text { Range pre- } \\
\text { race }\end{array}$ & $\begin{array}{l}\text { Median } \\
\text { finishers } \\
(n=25)\end{array}$ & $\begin{array}{l}\text { Range } \\
\text { finishers }\end{array}$ & $\begin{array}{l}\text { Median } \\
\text { withdrawn } \\
(n=9)\end{array}$ & $\begin{array}{l}\text { Range } \\
\text { withdrawn }\end{array}$ & $\begin{array}{l}\text { Median } \\
\text { controls } \\
(n=12)\end{array}$ & $\begin{array}{l}\text { Range } \\
\text { controls }\end{array}$ \\
\hline WBC & $\begin{array}{l}6.0- \\
18.0 \times 10 \mathrm{e} 9 / \mathrm{L}\end{array}$ & 12.6 & $7.7-18.4$ & 16.8 & $8.5-26.6$ & 17.1 & $9.8-28.4$ & 10.7 & $7.0-18.1$ \\
\hline $\mathrm{RBC}$ & $\begin{array}{l}5.1- \\
\quad 8.5 \times 10 \mathrm{e} 12 / \mathrm{L}\end{array}$ & 6.98 & $5.9-7.7$ & 6.21 & $4.76-7.31$ & 6.74 & $5.07-7.81$ & 7.85 & $7.07-8.97$ \\
\hline $\mathrm{HGB}$ & $120-180 \mathrm{~g} / \mathrm{L}$ & 165 & $133-186$ & 145 & $111-171$ & 158 & $114-179$ & 184 & $172-205$ \\
\hline $\mathrm{HCT}$ & $0.35-0.55 \mathrm{~L} / \mathrm{L}$ & 0.5 & $0.42-0.56$ & 0.44 & $0.34-0.53$ & 0.48 & $0.36-0.55$ & 0.56 & $0.52-0.63$ \\
\hline MCV & $62-76 \mathrm{fL}$ & 72.4 & $66.9-77.3$ & 72.6 & $67.5-76.9$ & 70.6 & $67.6-79.1$ & 70.9 & $66.1-76.9$ \\
\hline $\mathrm{MCHC}$ & $320-360 \mathrm{~g} / \mathrm{L}$ & 331 & $307-346$ & 330 & $323-338$ & 328 & $307-377$ & 332 & $318-350$ \\
\hline RDW & $11-16 \%$ & 14.4 & $12.7-16.7$ & 14.2 & $12.9-15.4$ & 13.7 & $12.7-14.9$ & 14 & $13.2-15.9$ \\
\hline PLT & $\begin{array}{l}180- \\
500 \times 10 \mathrm{e} 9 / \mathrm{L}\end{array}$ & 375 & $201-592$ & 293 & $202-592$ & 291.5 & $202-493$ & 303 & $227-414$ \\
\hline NEUT & $\begin{array}{l}3.6- \\
13.0 \times 10 \mathrm{e} 9 / \mathrm{L}\end{array}$ & 7.6 & $3.6-13.3$ & 13.7 & $6.8-22.5$ & 14.4 & $7.6-23.9$ & 6.7 & $4.0-11.2$ \\
\hline LYMPH & $0.8-5.8 \times 10 \mathrm{e} 9 / \mathrm{L}$ & 2.5 & $1.2-3.8$ & 1.6 & $1-3$ & 1.7 & $0.8-3.3$ & 2 & $1.5-4.2$ \\
\hline MONO & $0-1.6 \times 10 \mathrm{e} 9 / \mathrm{L}$ & 0.6 & $0.2-1.0$ & 0.8 & $0.4-1.7$ & 0.8 & $0.4-2.0$ & 0.4 & $0.2-0.8$ \\
\hline EOS & $0-1.8 \times 10 \mathrm{e} 9 / \mathrm{L}$ & 1 & $0.2-2.1$ & 0.1 & $0.1-2.1$ & 0.2 & $0.1-0.7$ & 1 & $0.3-6.6$ \\
\hline BASO & $0-0.4 \times 10 \mathrm{e} 9 / \mathrm{L}$ & 0.1 & $0.0-0.2$ & 0 & $0.0-0.1$ & 0.1 & $0.0-0.2$ & 0.1 & $0.0-0.1$ \\
\hline LUC & $0-1.5 \times 10 \mathrm{e} 9 / \mathrm{L}$ & 0.2 & $0.1-0.4$ & 0.1 & $0.0-0.4$ & 0.1 & $0.0-0.3$ & 0 & $0.0-0.1$ \\
\hline
\end{tabular}


Table 3 Median values and ranges for serum biochemistry values in all dogs in training, withdrawals, finishers and controls, along with reference range

\begin{tabular}{|c|c|c|c|c|c|c|c|c|c|}
\hline $\begin{array}{l}\text { Biochemistry } \\
\text { parameters }\end{array}$ & $\begin{array}{l}\text { Reference } \\
\text { range }\end{array}$ & $\begin{array}{l}\text { Median pre- } \\
\text { race all dogs } \\
(n=65)\end{array}$ & $\begin{array}{l}\text { Range pre- } \\
\text { race }\end{array}$ & $\begin{array}{l}\text { Median } \\
\text { finishers } \\
(n=25)\end{array}$ & $\begin{array}{l}\text { Range } \\
\text { finishers }\end{array}$ & $\begin{array}{l}\text { Median } \\
\text { withdrawn } \\
(n=21)\end{array}$ & $\begin{array}{l}\text { Range } \\
\text { withdrawn }\end{array}$ & $\begin{array}{l}\text { Median } \\
\text { controls } \\
(n=19)\end{array}$ & $\begin{array}{l}\text { Range } \\
\text { controls }\end{array}$ \\
\hline AST & $0-40 \mathrm{U} / \mathrm{L}$ & 31 & $18-92$ & 178 & $88-758$ & 375.5 & 89-2539 & 29 & $16-156$ \\
\hline ALT & $0-80 \mathrm{U} / \mathrm{L}$ & 59.5 & $35-186$ & 184 & $94-368$ & 174 & $62-662$ & 63 & $31-379$ \\
\hline AP & 0-90 U/L & 37 & $16-107$ & 61 & $26-176$ & 79 & $18-129$ & 34 & 18-101 \\
\hline CK & $0-200 \mathrm{U} / \mathrm{L}$ & 92 & $50-558$ & 1294 & $583-18,918$ & 1344.5 & $0-67,710$ & 86 & $39-6209$ \\
\hline AMYL & 0-1050 U/L & 361.5 & $152-927$ & 274 & $130-526$ & 204 & $5-1184$ & 400 & 213-705 \\
\hline TPROT & $54-75 \mathrm{~g} / \mathrm{L}$ & 63 & $55-71$ & 52 & $41-62$ & 51 & $38-64$ & 62 & $59-68$ \\
\hline ALB & $32-44 \mathrm{~g} / \mathrm{L}$ & 36 & $30-44$ & 30 & $24-37$ & 33 & $20-45$ & 37 & $34-44$ \\
\hline GLOB & $22-31 \mathrm{~g} / \mathrm{L}$ & 27 & $19-38$ & 21 & $17-26$ & 21 & $10-25$ & 24 & $22-28$ \\
\hline$A / G$ & $1.0-2.0$ & 1.37 & $0.79-2.00$ & 1.43 & $1.13-1.79$ & 1.465 & $1.04-4.50$ & 1.54 & $1.26-1.83$ \\
\hline UREA & $3.5-7.2 \mathrm{mmol} / \mathrm{L}$ & 6.9 & $4.0-10.3$ & 14.2 & $7.1-22.7$ & 13.45 & $7.6-24.1$ & 6.2 & $3.5-9.6$ \\
\hline CREAT & 65-110 $\mu \mathrm{mol} / \mathrm{L}$ & 76 & $60-96$ & 56 & $45-71$ & 53 & $39-71$ & 70 & $56-79$ \\
\hline $\mathrm{BA}$ & $0-10 \mu \mathrm{mol} / \mathrm{L}$ & 1 & $0-10$ & 3 & $1-15$ & 7 & $1-18$ & 2 & $0-9$ \\
\hline $\mathrm{CHOL}$ & $\begin{array}{l}3.4- \\
10.0 \mathrm{mmol} / \mathrm{L}\end{array}$ & 5.8 & $4.2-9.1$ & 5.5 & $4.0-8.1$ & 5.6 & $3.4-8.9$ & 5.2 & $3.4-7.9$ \\
\hline GLU & $3.6-6.6 \mathrm{mmol} / \mathrm{L}$ & 4.8 & $3.5-6.4$ & 5.5 & $4.0-7.6$ & 7.5 & $3.9-12.6$ & 5.9 & $4.8-6.9$ \\
\hline PHOSP & $0.9-2.0 \mathrm{mmol} / \mathrm{L}$ & 1.2 & $0.7-1.6$ & 1.4 & $0.9-1.9$ & 1.6 & $1.0-2.3$ & 1.2 & $0.8-1.8$ \\
\hline $\mathrm{Ca}$ & $2.2-2.9 \mathrm{mmol} / \mathrm{L}$ & 2.5 & $2.2-2.7$ & 2.2 & $2.0-2.4$ & 2.15 & $1.9-2.4$ & 2.4 & $2.3-2.5$ \\
\hline $\mathrm{Na}$ & $\begin{array}{l}140- \\
154 \mathrm{mmol} / \mathrm{L}\end{array}$ & 148 & $146-151$ & 148 & $146-152$ & 147 & $142-151$ & 149 & $147-151$ \\
\hline K & $3.7-5.8 \mathrm{mmol} / \mathrm{L}$ & 4.7 & $3.9-5.3$ & 3.8 & $3.3-4.3$ & 3.85 & $3.1-4.7$ & 5.1 & $4.8-5.5$ \\
\hline $\mathrm{Na} / \mathrm{K}$ & $>27.0$ & 31.3 & $27.9-37.7$ & 39.5 & $34.4-45.8$ & 37.9 & $30.6-46.8$ & 29.4 & $26.7-31.5$ \\
\hline $\mathrm{Cl}$ & 99-115 mmol/L & 113 & $107-118$ & 116 & $111-123$ & 113 & $108-120$ & 113 & $110-116$ \\
\hline CRP & 0-15 mg/L & 18.7 & $1.2-78.9$ & 75.1 & 27-192 & 93.05 & $22-220$ & 3.2 & $0.0-156.9$ \\
\hline CORT & 20-250 nmol/L & 58 & $14-141$ & 147 & $74-323$ & 80.5 & $46-224$ & 52 & $34-125$ \\
\hline
\end{tabular}

differences. For all of the above analyses, we used a significance threshold of $<0.0001$ due to the high number of comparisons being undertaken. In addition, demographic covariate interactions were explored but were not included in our final models due to low model support, as evaluated by likelihood-ratio tests between the simpler and interaction-term models.

Study design and the comparisons between the different cohorts are illustrated in Fig. 1.

\section{Results}

Three kennels with a total of 47 Alaskan huskies and one kennel containing 18 Siberian huskies were included. There were 32 females and 33 males with a mean age of 3.8 years (range 1-9 years). Forty-six dogs were race participants, while 19 dogs served as controls. Three mushers and 25 dogs completed the race within 3 to 4 days. Twenty-one dogs, including a complete team of 12 dogs, were dismissed at different times during the race.

Each dog was considered healthy at the time of prerace as well as at post-race sampling when referring to the controls and finishers, as no clinical signs of illness were observed. Withdrawals were dismissed due to lameness, depression, anorexia and/or dehydration. The main reason for withdrawal of a whole team was anorexia in several dogs. Seven withdrawals had been fed at the checkpoint prior to blood sampling. Based on information from the mushers, collected via questionnaires, training and feeding routines prior to the race were considered equal for all dogs.

Due to storage failure, 19 pre-race EDTA samples had to be excluded, leading to removal of the matching post-race samples. Hence, the number of EDTA samples included was 9 in the withdrawal group and 12 in the control group.

The median and range values from the three cohorts before training and post-race are presented in Tables 2 and 3. Results for serum biochemistry and haematological values in the regression model, where the variables age, sex and owner are included, are listed in Additional file 1. 

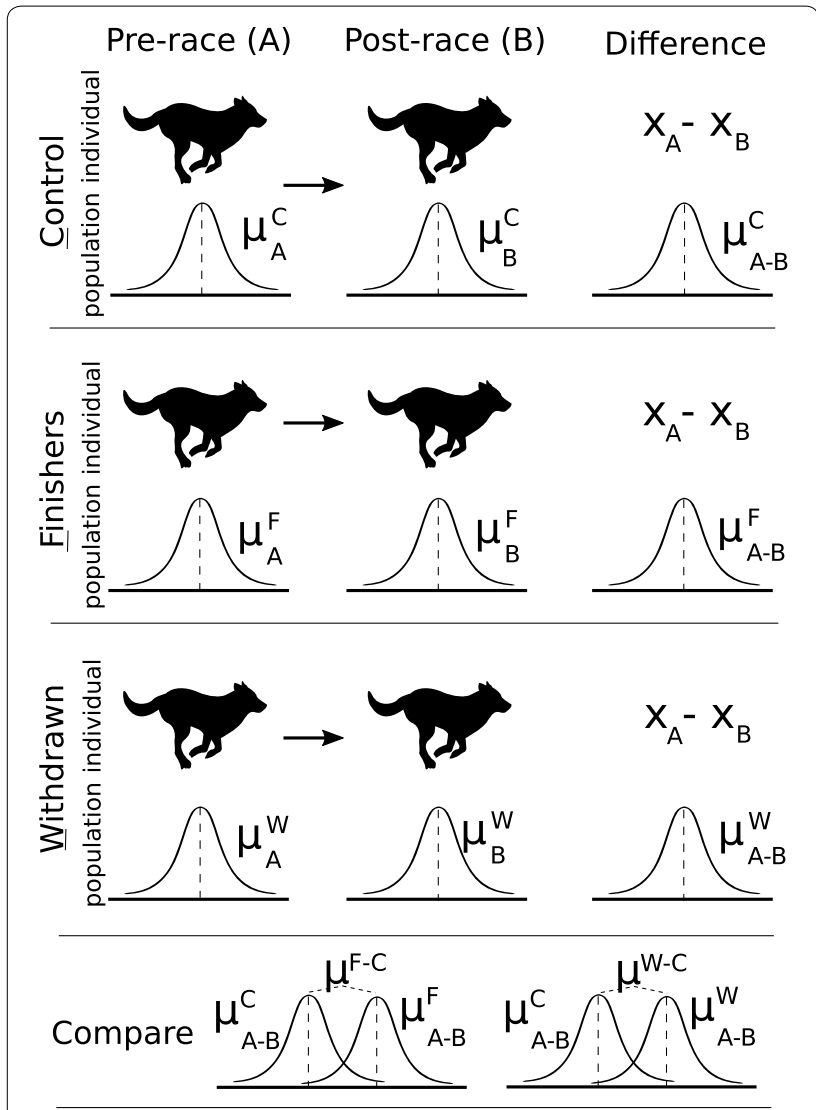

Null hypothesis $\mu^{\mathrm{F}-\mathrm{C}}=0 \quad \mu^{\mathrm{W}-\mathrm{C}}=0$

Fig. 1 Study design and the comparisons between the cohorts; withdrawals, finishers and controls

\section{Haematology}

The increase in neutrophil cell count was significantly greater in withdrawn dogs $(\mathrm{P}<0.0001)$, and the decrease in erythrocytes (RBC), haematocrit (HCT), haemoglobin (HGB) and eosinophils was significantly lower $(\mathrm{P}<0.0001)$ compared to the controls.

In finishers, the increase in white blood cell count (WBC), large unstained cell count (LUC), neutrophils and monocytes was significantly greater $(\mathrm{P}<0.0001)$ compared to controls, while the decrease in RBC, HCT, HGB and eosinophils was significantly lower $(\mathrm{P}<0.0001)$.

$\mathrm{RBC}, \mathrm{HGB}$ and HCT were significantly higher and LUC significantly lower in the controls' B samples $(\mathrm{P}<0.0001)$ compared to results from the A samples from all three cohorts during training.

No haematological parameters showed any significant difference in owner, gender or age effect.

\section{Serum enzyme activities}

The increase in aspartate aminotransferase (AST), CK (log scale) (Fig. 2), alanine aminotransferase (ALT) and alkaline phosphatase (AP) were significantly greater in withdrawals only $(\mathrm{P}<0.0001)$ compared to controls.

\section{Blood urea nitrogen and creatinine concentrations}

The increase in blood urea nitrogen (BUN) was significantly higher and the decrease in creatinine concentration significantly lower in both withdrawals and finishers compared to controls $(\mathrm{P}<0.0001)$. Additionally, the decrease in creatinine was significantly lower in the B-samples from the controls compared to A-samples from all three cohorts $(\mathrm{P}<0.0001)$.

\section{Serum protein concentrations}

The decrease in albumin, globulin and total protein was significantly lower in both withdrawn and finishing dogs compared to controls $(\mathrm{P}<0.0001)$. Albumin and globulin were significantly influenced by the owner variable $(\mathrm{P}<0.0001)$.

\section{Glucose and cholesterol}

The increase in glucose was significantly higher and the decrease in cholesterol significantly lower in B samples from the controls compared to A samples from all three cohorts $(\mathrm{P}<0.0001)$.

\section{Electrolytes and mineral concentrations}

In withdrawals, the elevation in phosphorus concentration was significantly higher compared to controls $(\mathrm{P}<0.0001)$. The decrease in calcium and potassium levels were significantly lower $(\mathrm{P}<0.0001)$ and the increase in sodium/potassium significantly higher in both withdrawals and finishers $(\mathrm{P}<0.0001)$. The decrease in calcium was significantly lower in the controls when comparing their $\mathrm{B}$ samples to all A samples from the three cohorts $(\mathrm{P}<0.0001)$. The level of phosphorus was significantly influenced by the owner $(\mathrm{P}<0.0001)$.

\section{C-reactive protein and cortisol}

The elevation in C-reactive protein (CRP) was significantly higher in both withdrawals and finishers compared to controls $(\mathrm{P}<0.0001)$, and the increase in cortisol was significantly greater only in the finishers $(\mathrm{P}<0.0001)$.

No biochemistry parameters were influenced by age or gender.

Correlation plots for haematology and biochemistry parameters are presented in Fig. 3. 


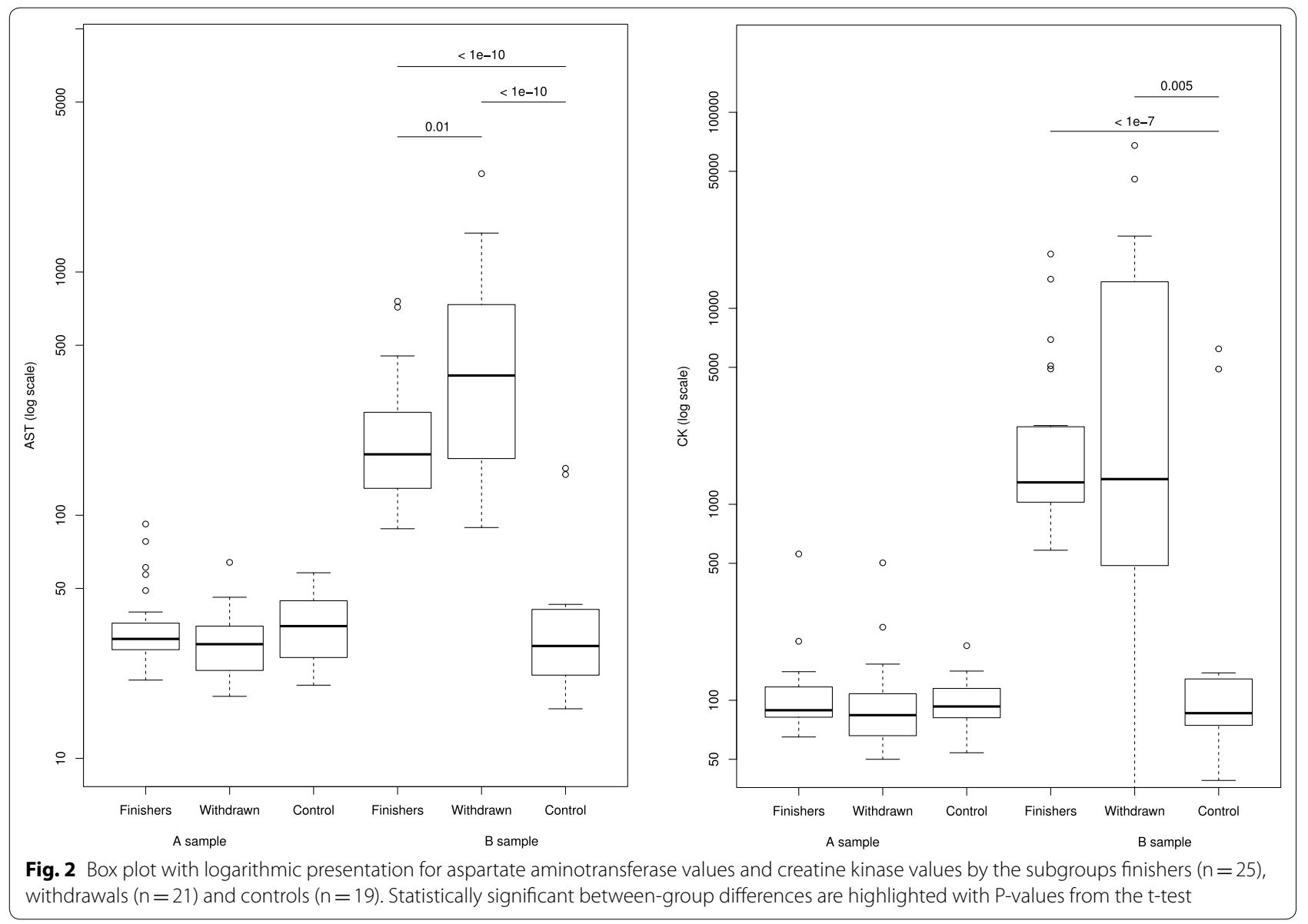

\section{Discussion}

The number of scientific publications presenting complete haematological and serum biochemistry profiles in dogs participating in endurance activities is limited. This report includes a survey of both haematological and biochemical parameters from the same individuals before and after long distance racing. Stress prior to a race may influence the results of blood analysis [10]. By comparing post-race results with outcomes from samples taken during the training season, and not immediately prior to race start, the possible impact from anticipation, stress and environmental challenges normally present at this stage, was eliminated.

Many significant findings observed in this study were found both in the withdrawals and the finishers, most of them were minor and relative changes within reference ranges. Studies regarding estimates of biologic variation have revealed high individual variation of many routinely measured analytes $[11,12]$. Hence, biologic variation may have accounted for minor alterations in the blood parameters analysed. This might indicate that many of the observed changes simply reflect physiological adaption due to endurance exercise, and that the majority of racing sled dogs cope well.

However, significant increases in the muscle enzymes AST and CK were seen in the withdrawn group when compared to the control dogs. Unlike most other significant findings, median values of muscle enzymes were also well above reference range in this group. Some of the withdrawals, demonstrating particularly elevated muscle enzymes, had clinical signs that could be related to rhabdomyolysis. Other studies also report that elevations in muscle enzymes in racing sled dogs can be clinically relevant, and might indicate rhabdomyolysis and performance failure [13-15].

Moderate increases in AST and CK due to musculoskeletal catabolism are also expected in healthy sled dogs $[1,2,13,14,16]$. The median values of CK and AST were also above the upper reference range in the finisher group. However, significant changes were not detected when comparing the finishing cohort to the control group. C-reactive protein was significantly increased in both withdrawn and finishers. In addition, CRP was above reference range, which may reflect an 

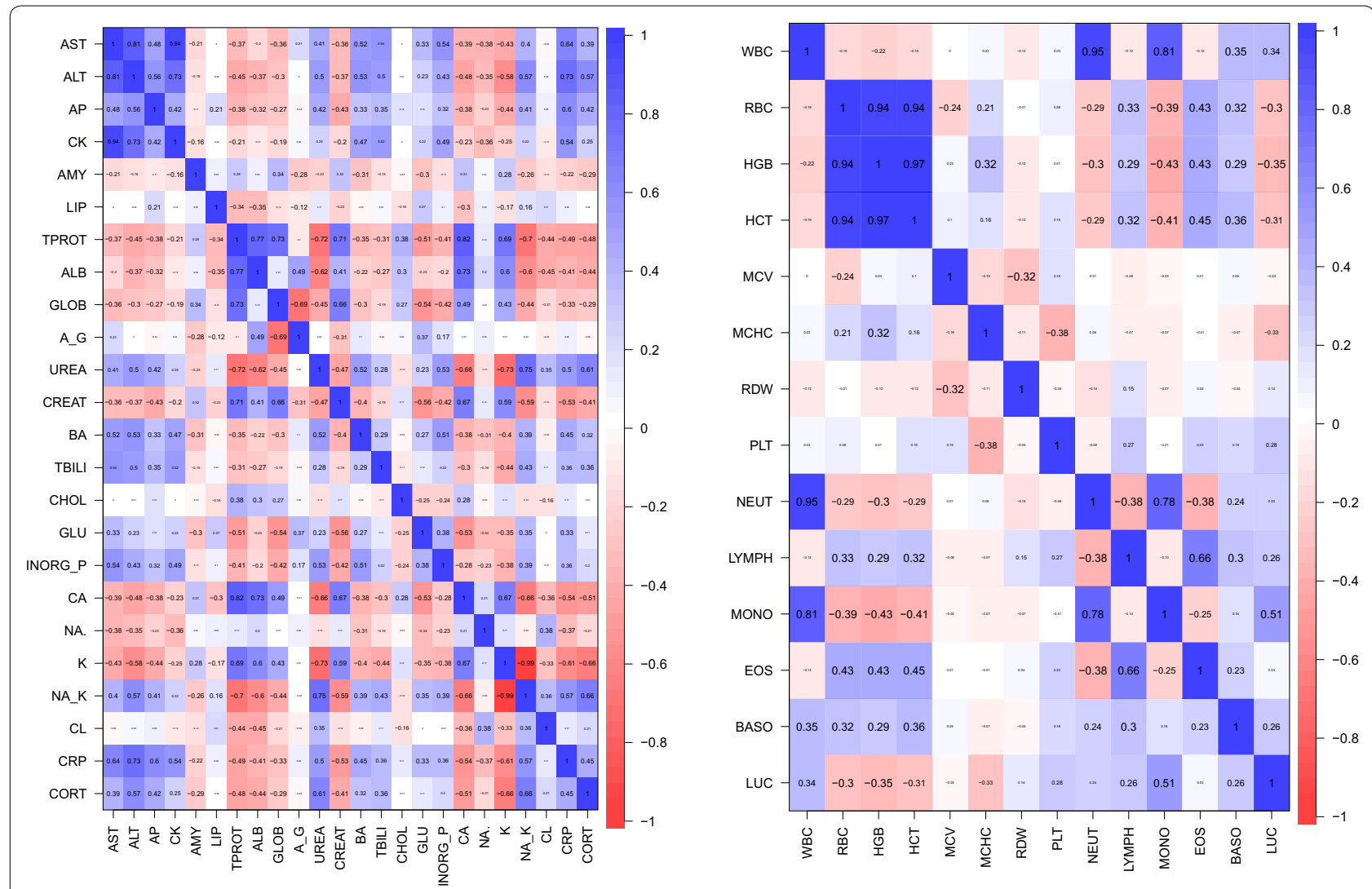

Fig. 3 Correlation plots illustrating positive (blue colour) and negative (red colour) correlations between the different haematological and serum biochemistry parameters

interaction with muscle degradation and an inflammatory response, also stated previously [17].

The significant elevations in ALT and AP among the withdrawals may reflect a reactive hepatopathy, possibly secondary to increased metabolic demands and gastrointestinal dysfunction during heavy exercise. Similar changes are observed in marathon runners, post-exercise [18]. It has also been suggested that an increase in ALT in racing sled dogs is due to muscle degradation, rather than hepatic damage [2, 19].

There has been speculation whether racing sled dogs may experience transient kidney dysfunction [20], which has been reported in human marathon runners [21]. In this study, both withdrawals and finishers showed a significant decrease in creatinine concentration and a significant increase in BUN. However, these findings were relative changes within reference range. This correlates with most previous reports $[1,13,14]$. A relative increase in BUN with normal or decreased creatinine is thought to be the result of high dietary protein intake combined with increased protein catabolism during racing $[2,14]$.
Significant decreases in RBC, HGB and HCT, as well as globulin, albumin and total protein, were observed in both withdrawals and finishers when compared to controls. Still, all findings were relative changes within reference range. These results correlates with previous reports $[3,14]$, and are mainly thought to be caused by plasma volume expansion during physical exercise $[1-3,14,22]$. However, sled dogs during endurance racing are at high risk of developing gastrointestinal illness, like enteritis, gastritis and gastric ulceration [5], and gastrointestinal loss of red blood cells and proteins cannot be excluded as cause of the observed changes in HCT and proteins, both in withdrawals and finishers $[6,23]$.

Both withdrawn and finishing dogs experienced a significant increase in neutrophils, as well as a decrease in eosinophils compared to controls. In finishers, significant increases in WBC and monocytes were also observed. A similar WBC response is observed during long-distance running, both in humans and sled dogs $[3,24]$, which is an expected physiological response during heavy exercise [3]. An increase in endogen cortisol is considered partially responsible for the observed stress leukogram observed after exercise in humans and horses $[25,26]$, 
and should also be suspected as a cause in canine athletes. The significant elevation in cortisol observed in the finishing dogs in this study, supports the exerciseinduced increase in cortisol recognized in sled dogs in previous studies $[27,28]$.

\section{Limitations}

It was not possible to completely standardize storage of the blood sample. Time from sampling to analysis differed between some of the groups and may have affected especially the haematological results [29]. Delayed sampling in some of the withdrawals may also have allowed for some degree of restoration, and the observed changes may have been underestimated, especially in parameters with short serum half-life. Some withdrawals were fed prior to post-race sampling. This may have had an impact on some of the blood results, however, CK and AST results should not be markedly influenced.

The Central laboratory is a reference laboratory with high level of quality assurance, however, all biochemical samples could not be run the same day which may have increased analytical imprecision.

Some haematological samples were unfortunately not included in the statistical analysis due to storage failure of their pre-race EDTA tubes. However, the number of remaining samples was still sufficient to support the statistical significance in the presented results.

\section{Conclusions}

The majority of the statistically significant biochemical and haematological changes in dogs competing in a $600 \mathrm{~km}$ race were minor and often within reference range. Although often more pronounced in withdrawn dogs, significant changes were also observed in the finishing group, probably reflecting physiological adaption due to exercise rather than illness. However, only withdrawals experienced a significant elevation in muscle enzymes with values high above reference range, indicating muscle damage as a possible explanation for being retired from the race.

\section{Additional file}

Additional file 1. Coefficients from the multivariable regression analysis, explaining how each demographic variable (cohort, age, sex and owner) relates to a particular haematological/serum biochemistry parameter.

\section{Abbreviations}

CK: creatine kinase; RBC: erythrocytes/red blood cell count; HCT: haematocrit; HGB: haemoglobin; WBC: white blood cell count; LUC: large unstained cell count; AST: aspartate aminotransferase; ALT: alanine aminotransferase; AP: alkaline phosphatase; BUN: blood urea nitrogen; CRP: C-reactive protein.

\section{Authors' contributions}

MEF and THJ participated in the design and coordination of the study and carried out the sample collection. This was done as their final year research project at the Norwegian School of Veterinary Science. THJ drafted the manuscript. OB performed the statistical analysis in this project. ES initiated the study as supervisor for the final year research project, participated in the design and coordination of the study and helped to draft the manuscript. $\mathrm{HBH}$ helped to draft the manuscript. All authors read and approved the final manuscript.

\section{Author details \\ ${ }^{1}$ Department of Companion Animal Clinical Sciences, Faculty of Veteri- nary Medicine, Norwegian University of Life Sciences, PO Box 8146 Dep, 0033 Oslo, Norway. ${ }^{2}$ Department of Food Safety and Infection Biology, Faculty of Veterinary Medicine, Norwegian University of Life Sciences, PO Box 8146 Dep, 0033 Oslo, Norway. ${ }^{3}$ Department of Infectious Disease Epidemiology and Modelling, Norwegian Institute of Public Health, Lovisenberggata 8, 0456 Oslo, Norway.}

\section{Acknowledgements}

The authors would like to thank the participating mushers, all involved staff at Femundløpet 2013, participating vet nurse Dagrun Hansen Lia at Norwegian University of Life Sciences and the employees at The Central Laboratory at Norwegian University of Life Sciences, especially Stein Istre Thoresen for helpful feedback.

\section{Competing interests}

The authors declare that they have no competing interests.

\section{Availability of data and materials}

The intercept values supporting the conclusions of this article are included as Additional file 1 (pdf).

\section{Ethics approval and consent to participate}

This study was performed in 2012-2013. At that time, approval from the Norwegian Animal Research Committee or other institutions was not required.

\section{Funding}

"Smådyrpraktiserende veterinærers forenings faglige og vitenskapelige fond" and "Dyrlege Smiths legat" contributed with economic funding to this project.

\section{Publisher's Note}

Springer Nature remains neutral with regard to jurisdictional claims in published maps and institutional affiliations.

Received: 9 August 2018 Accepted: 15 April 2019

Published online: 25 April 2019

\section{References}

1. McKenzie EC, Jose-Cunilleras E, Hinchcliff KW, Holbrook TC, Royer C, Payton ME, et al. Serum chemistry alterations in Alaskan sled dogs during five successive days of prolonged endurance exercise. J Am Vet Med Assoc. 2007;230:1486-92.

2. Ermon V, Yazwinski M, Milizio JG, Wakshlag JJ. Serum chemistry and electrolyte alterations in sled dogs before and after a $1600 \mathrm{~km}$ race: dietary sodium and hyponatraemia. J Nutr Sci. 2014;3:e26.

3. Davis MS, Davis WC, Ensign WY, Hinchcliff KW, Holbrook TC, Williamson KK. Effects of training and strenuous exercise on hematologic values and peripheral blood leukocyte subsets in racing sled dogs. J Am Vet Med Assoc. 2008;232:873-8.

4. Kronfeld DS, Hammel EP, Ramberg CF Jr, Dunlap HL Jr. Hematological and metabolic responses to training in racing sled dogs fed diets containing medium, low, or zero carbohydrate. Am J Clin Nutr. 1977;30:419-30.

5. Dennis MM, Nelson SN, Cantor GH, Mosier DA, Blake JE, Basaraba RJ. Assessment of necropsy findings in sled dogs that died during Iditarod Trail sled dog races: 23 cases (1994-2006). J Am Vet Med Assoc. 2008;232:564-73. 
6. Davis MS, Willard MD, Nelson SL, Mandsager RE, McKiernan BS, Mansell JK, et al. Prevalence of gastric lesions in racing Alaskan sled dogs. J Vet Intern Med. 2003;17:311-4.

7. Fergestad ME, Jahr TH, Krontveit Rl, Skancke E. Serum concentration of gastrin, cortisol and C-reactive protein in a group of Norwegian sled dogs during training and after endurance racing: a prospective cohort study. Acta Vet Scand. 2016;58:24.

8. R Core Team. R: a language and environment for statistical computing. 2016. https://www.R-project.org/. Accessed 14 Feb 2018

9. Revelle W. psych: procedures for personality and psychological research. 2016. https://CRAN.R-project.org/package=psych. Accessed 14 Feb 2018.

10. Angle CT, Wakshlag JJ, Gillette RL, Stokol T, Geske S, Adkins TO, et al. Hematologic, serum biochemical, and cortisol changes associated with anticipation of exercise and short duration high-intensity exercise in sled dogs. Vet Clin Pathol. 2009;38:370-4.

11. Ruaux CG, Carney PC, Suchodolski JS, Steiner JM. Estimates of biological variation in routinely measured biochemical analytes in clinically healthy dogs. Vet Clin Pathol. 2012;41:541-7.

12. Carney PC, Ruaux CG, Suchodolski JS, Steiner JM. Biological variability of C-reactive protein and specific canine pancreatic lipase immunoreactivity in apparently healthy dogs. J Vet Intern Med. 2011;25:825-30.

13. Hinchcliff KW, Olson J, Crusberg C, Kenyon J, Long R, Royle W, et al. Serum biochemical changes in dogs competing in a long-distance sled race. J Am Vet Med Assoc. 1993;202:401-5.

14. Burr JR, Reinhart GA, Swenson RA, Swaim SE, Vaughn DM, Bradley DM Serum biochemical values in sled dogs before and after competing in long-distance races. J Am Vet Med Assoc. 1997;211:175-9.

15. Hinchcliff KW, Shaw LC, Vukich NS, Schmidt KE. Effect of distance traveled and speed of racing on body weight and serum enzyme activity of sled dogs competing in a long-distance race. J Am Vet Med Assoc. 1998:213:639-44

16. Hinchcliff K, Constable P, DiSilvestro R. Muscle injury and antioxidant status in sled dogs competing in a long-distance sled dog race. Equine Comp Exerc Physiol. 2004;1:81-5.

17. Fallon KE. The acute phase response and exercise: the ultramarathon as prototype exercise. Clin J Sport Med. 2001;11:38-43.

18. Traiperm N, Gatterer H, Pariwat P, Burtscher M. Energy metabolism, liver and kidney function in adolescent marathon runners. Eur J Clin Invest. 2016:46:27-33.
19. Querengaesser A, Iben C, Leibetseder J. Blood changes during training and racing in sled dogs. J Nutr. 1994;124:2760s-4s.

20. Hinchcliff KW, Reinhart GA, Burr JR, Swenson RA. Exercise-associated hyponatremia in Alaskan sled dogs: urinary and hormonal responses. J Appl Physiol. 1997:83:824-9.

21. McCullough PA, Chinnaiyan KM, Gallagher MJ, Colar JM, Geddes T, Gold $J M$, et al. Changes in renal markers and acute kidney injury after marathon running. Nephrology. 2011;16:194-9.

22. Hinchcliff KW, Reinhart GA, Burr JR, Schreier CJ, Swenson RA. Effect of racing on serum sodium and potassium concentrations and acid-base status of Alaskan sled dogs. J Am Vet Med Assoc. 1997;210:1615-8.

23. Davis MS, Willard MD, Williamson KK, Steiner JM, Williams DA. Sustained strenuous exercise increases intestinal permeability in racing Alaskan sled dogs. J Vet Intern Med. 2005;19:34-9.

24. Wu HJ, Chen KT, Shee BW, Chang HC, Huang YJ, Yang RS. Effects of $24 \mathrm{~h}$ ultra-marathon on biochemical and hematological parameters. World $J$ Gastroenterol. 2004;10:2711-4.

25. Kingston JK. Hematologic and serum biochemical responses to exercise and training. In: Hinchcliff K, Geor R, Kaneps A, editors. Equine exercise physiology. Philadelphia: Saunders Elsevier; 2008. p. 398-409.

26. Brenner I, Shek PN, Zamecnik J, Shephard RJ. Stress hormones and the immunological responses to heat and exercise. Int J Sports Med. 1998;19:130-43.

27. Durocher LL, Hinchcliff KW, Williamson KK, McKenzie EC, HolbrookTC, Willard $M$, et al. Effect of strenuous exercise on urine concentrations of homovanillic acid, cortisol, and vanillylmandelic acid in sled dogs. Am J Vet Res. 2007:68:107-11.

28. Royer CM, Willard M, Williamson K, Steiner JM, Williams DA, David M. Exercise stress, intestinal permeability and gastric ulceration in racing Alaskan sled dogs. Equine Comp Exerc Physiol. 2005;2:53-9.

29. Bourges-Abella NH, Geffre A, Deshuillers PL, Braun JP, Trumel C. Changes in hematology measurements in healthy and diseased dog blood stored at room temperature for 24 and 48 hours using the XT-2000iV analyzer. Vet Clin Pathol. 2014:43:24-35.
Ready to submit your research? Choose BMC and benefit from:

- fast, convenient online submission

- thorough peer review by experienced researchers in your field

- rapid publication on acceptance

- support for research data, including large and complex data types

- gold Open Access which fosters wider collaboration and increased citations

- maximum visibility for your research: over $100 \mathrm{M}$ website views per year

At $\mathrm{BMC}$, research is always in progress.

Learn more biomedcentral.com/submissions 